Bartın Üniversitesi İktisadi ve İdari Bilimler Fakültesi Dergisi, 2020, Cilt 11, Sayı 22

Bartın University Journal of Faculty of Economics and Administrative Sciences, 2020, Volume 11, Issue 22

ISSN: 1309-954X / E-ISSN: 2148-2497

http://iibfdergi.bartin.edu.tr/

http://dergipark.gov.tr/bartiniibf

Araştırma Makalesi, Gönderim Tarihi: 18.09.2020; Kabul Tarihi: 28.11.2020

\title{
Kooperatiflerde Oryantasyon Eğitim Programının Değerlendirilmesi: Bir Araştırma
}

\author{
Dr. Abdulkadir FASAL \\ Türkiye Tarım Kredi Kooperatifleri \\ abdulkadir_fasal@hotmail.com, Orcid ID: 0000-0002-6997-3236
}

\section{$\ddot{O} \mathbf{z}$}

İşe yeni başlayan çalışanlara işe uyumunu kolaylaştırmak, yapacağı işe ilişkin özellikleri, işletmenin amaç ve hedeflerini, misyon ve vizyonunu anlatmak amaciyla işletmeler tarafından oryantasyon eğitimleri düzenlenmektedir. $\mathrm{Bu}$ çalışmada, çalışanların almış oldukları oryantasyon eğitimini ve bu eğitimin çalışma hayatındaki etkisini değerlendirmeleri yer almaktadır. Veri toplama yöntemi olarak anket kullanılmış olup 2019 yılı içerisinde işe başlayan ve oryantasyon eğitimi alan 89 çalışana eğitim programı sonunda eğitim değerlendirme, oryantasyon eğitimi içeriği değerlendirme ve 9 aylık çalışma süreleri sonunda ise oryantasyon eğitimi- çalışma hayatı değerlendirme anketleri uygulanmıştır. Bu kapsamda elde edilen bulgularda oryantasyon eğitiminin çalışanların işe uyumunu kolaylaştırdığı ve işe başlayan her çalışana mutlaka oryantasyon eğitimi verilmesi gerektiği görülmüştür. Bununla birlikte bulgularda dikkat çeken bir husus oryantasyon eğitiminin içeriğinin uygulamaya yönelik olması gerektiğidir.

Anahtar Kelimeler: Oryantasyon, Kooperatif, Eğitim

JEL Sınıflandırması: M12,M53 


\title{
Evaluation of Orientation Training Program in Cooperatives: A Research
}

\begin{abstract}
Orientation trainings are organized by businesses for the purpose of facilitating the compliance of new employees, explaining the characteristics of the work s/he will do, explaining the purpose and objectives of the business, its mission and vision. In the present study, the evaluations of the employees on the orientation training and the effect of this training in working life are included. The questionnaires were used as data collection method, and 89 employees who started to work in 2019 and received orientation training were included in the study. The fields included were the evaluations made by the employees at the end of the training program, evaluation of the contents of the orientation training, and orientation training-working life evaluation questionnaires at the end of the 9-month working period. It was observed in the findings obtained in this scope that the orientation training facilitated the harmony of employees to work, and that orientation training should be given to every employee who starts work. However, one thing that was noted in the findings was that the contents of the orientation training should be intended for practice.
\end{abstract}

Keywords: Orientation, Cooperative, Education

JEL Classification: M12,M53

\section{Giriş}

Değişimin çok hızlı yaşandığı günümüzde işletmelerin rakipleri ile rekabet edebilmesi ve belirledikleri hedeflere ulaşabilmesi noktasında çalışanlar kritik öneme sahiptir. Özellikle emeğin çok yoğun olarak kullandığı hizmet sektöründe ise bu daha da önemli hale gelmektedir. Çalışanların örgüte uyumunu artırmak amacıyla kurumsallaşmanın bir gereği olan ve isteğe bağlı olarak uygulanan oryantasyon (işe alıştırma) eğitimi büyük bir önem arz etmektedir (Çakır ve Kacır, 2018, 125). Bu bağlamda işletmeler işe aldıkları çalışanlarının en kısa sürede örgüte uyum sağlamasını ve işletmeye katkıda bulunmasını istemektedir. İşletmeler bu doğrultuda yeni işe aldıkları çalışanların kuruma kısa sürede uyum sağlamaları, işletmeninin amaç ve hedefleri, çalışanların yapacakları iş ile çalışanlardan beklentilerini dile getirecekleri bununla birlikte çalışanlarında beklentilerini, duygu ve düşüncelerini dile getirebilecekleri oryantasyon eğitim programları düzenlemektedir. $\mathrm{Bu}$ program bir bakıma çalışanlara örgütü ve işi tanıtma, çalışanları tanıma şeklinde tasarlanmaktadır.

Oryantasyon eğitim programının içeriğinin, süresinin doğru şekilde planlanması eğitimin başarılı olması açısından önemlidir. Aksi durumda eğitim hem işletme açısından hem de çalışan açısından boşa geçen zaman olacaktır. Bu durumda çalışanın işe adaptasyon süresi uzayacak, belki de bu süreç çalışanın işten ayrılmasına kadar 
gidebilecektir. Bu nedenlerden dolayı oryantasyon eğitimi çalışanların işe alım süreci kadar önem arz etmektedir.

Kooperatifler çok sayıda farklı işin yapıldığı emek yoğun hizmet işletmeleridir. Bununla birlikte kooperatiflerin çalışma sistemleri, yapısı, işleyişi diğer işletmelerden farklılıklar göstermektedir. Bunun için kooperatiflerde yeni personel alımı sonrasında oryantasyon eğitim içeriğinin doğru şekilde oluşturulması, çalışanların sonradan yaşayabileceği sorunların önüne geçecektir.

\section{Oryantasyon Eğitiminin Tanımı ve Amacı}

Eğitim insanların doğumuyla başlayan ve hayatının sonuna kadar devam eden çok aşamalı bir süreçtir. Eğitim insanların sosyal hayatının ve iş hayatının vazgeçilmezi olmazsa olmazıdır. Bu bağlamda işlerin doğru ve etkin bir şekilde yerine getirilmesi için yeni bir konuya ilişkin insanların ihtiyaç duyduğu bilgilerin kazandırılması için eğitim programları düzenlenmektedir. Bu kapsamda ele alındığında insanlar farkında olsun veya olmasın sürekli bir eğitim sürecinden geçmektedir.

İnsanların, günlük hayatlarının büyük bir kısmını geçirdikleri iş yaşamında ihtiyaç duydukları bilgilere ulaşması, bulunduğu işletmeye ve örgüte uyum sağlaması, işe bağlılığının arttırılmasında eğitimin büyük rolü vardır. $\mathrm{Bu}$ bağlamda eğitim fonksiyonun bir parçası olan oryantasyon eğitimi önemli hale gelmektedir.

İşe alınan yeni çalışanların sosyalleşmesi olarak da ifade edilen oryantasyon eğitimi, çalışanların örgütün amaç ve hedeflerini, politikalarını örgüt kültürünü, işleyişini, yapısını ve kendi görev, yetki ve sorumluluklarını (Harvey ve Bowin, 1996: 160), çalışanlara iş hayatında hangi bilgilere ne zaman ihtiyaç duyacağını, iş yerinin organizasyon yapısı ve politikaları hakkında bilgi sunan ( Mathis ve Jackson, 1991, Mestre ve diğ., 1997: 446), personelin örgüte ve işe uyum süresini kısaltmak için çalışacağı bölüm ve yapacağı işler hakkında bilgi vererek onlara kendilerini işletmenin bir parçası olarak görmelerini sağlayan eğitim faaliyetidir (Byars ve Rue, 2000: 205, Cascio, 1992; 223). Diğer bir ifadeyle oryantasyon eğitimi işe yeni başlayan işgörene işletmenin tarihine, işlerdeki davranış biçimlerine, kültürüne, fiziki ve sosyal alt yapısına yönelik genel bilgilerin verildiği bir işe alıştırma ve uyumlaştırma sürecidir (Mirze, 2010, 183, Çakır ve Kacır, 2018, 125) Oryantasyon eğitimi işe yeni başlayan çalışanın beklentileri ile işyerinin beklentilerinin entegrasyonunu sağlanmaktadır (Mestre ve diğ., 1997: 443).

Oryantasyon eğitimi ile işe alınan çalışanların yeni bir işe başlarken yaşayabilecekleri gerilimleri, sıkıntıları, yeni bir örgüte uyum sağlamada yaşanacak kültür şoklarını en aza indirgemek amaçlanmaktadır ( De Cenzo ve Robbins, 1996: 220, Noe ve diğ., 2009: 202, Dessler, 1994: 235) . Ayrıca işletmede çalışanların seçim aşaması ne kadar iyi olursa olsun, bu durum alınan yeni personelin yüksek performans göstereceğini garanti etmemektedir. Çünkü seçilen kişi çok yüksek potansiyelli çalışan 
olsa bile yapacağı işin ne olduğunu ve bu işi nasıl yapacağını bilememektedir. Bu bağlamda oryantasyon eğitiminin önemli amaçlarından bir tanesi de çalışanlara ne yapacakları ve nasıl yapacakları konusunda bilgi vermektir (Çetin ve diğ.,2018 ).

Oryantasyon eğitimi ile işin gerektirdiği tutum ve bilgilerin edinilmesi, düşünsel ve bedensel becerilerin kazandırılması yoluyla yeni çalışanın işe ve işletmeye uyumunun en kısa zamanda sağlanması (Kocabacak, 2010: 18-19), böylelikle çalışanların işletmeye yabancılaşmasına engel olmak ve çalışanların sosyal olarak kaynaşması amaçlanmaktadır (Çakır ve Kacır, 2018, 126).

Oryantasyon eğitimi çalışanlarda örgüte ait olma, kendisine işi başarabileceği noktasında güven oluşturma hissi oluşturarak çalışanların işyerine uyum sorunu yaşamalarını ve başarısız olma duygusunun azalmasını sağlayarak çalışanların kendine olan güvenin yükselmesini sağlamaktadır (Latif ve Uçkun, 2002: 38). Bu açıdan bakıldığında oryantasyon eğitiminin diğer bir amacı da işe yeni başlayan çalışanların kendilerine olan güvenlerini desteklemek ve güçlendirmektir (Mathis ve Jackson, 1997: 158).

İşe yeni alınan çalışanların yeni iş çevrelerini öğrenmelerine yardımcı olmak, oryantasyon eğitiminin bir diğer temel amacı olmakla birlikte; işe yeni başlayan kişide olumlu bir izlenim yaratma, kişiler arası kabulü artırma ve bireysel ve örgütsel performansı artırmak da diğer amaçlarını ifade etmektedir (Bingöl, 2010: 284-285).

\section{Oryantasyon Eğitiminin Önemi}

İşletmelerin rekabetin yoğun olarak yaşandığı bu dönemlerde faaliyetlerini devam ettirebilmelerinin koşullarından biri de nitelikli personel istihdam etmeleridir. Fakat istihdam edilen çalışan ne kadar yetenekli, donanımlı olsa da yeni bir işe, yeni bir örgüte girdiğinden bu yapı hakkında çok bir bilgisi yoktur. Yeni işe alınan personelin başarıya ulaşması yeni işe başladığı örgüte en kısa zamanda uyum sağlaması, görev ve sorumluluklarını en kısa sürede öğrenmesi ile mümkündür. Bu bağlamda, oryantasyon eğitimi işe alınan personelin yapacağı işi öğrenmesi ve kendisi ile birlikte çalışacağı iş arkadaşlarına, yöneticilerine tanıtılması açısından önemlidir ( Tiyek, 2014; 336). Öte yandan oryantasyon eğitimi yeni personelin örgütü tanımasına yardımcı olarak personelin örgütteki diğer çalışanların değerlerini, normlarını ve inançlarını anlayarak sosyalleşmesini hızlandırmaktadır (Ünsar, 2003: 83, Karakaş, 2014: 5).

Oryantasyon eğitimi ile çalışanların işten ayrılmaları en aza indirilebilir ve böylelikle çalışanlar için harcanan emek ve zaman kaybının önüne geçilebilir. Bu eğitim ile yeni bir işe başlamanın getirmiş olduğu gerilimler hafifletilebilir ve kısa sürede işe yatkınlık sağlayabilir, çalışanda örgüte ve işe dönük olumlu tutum ve davranışlar geliştirebilir. Çalışanın örgüte yabancılaşmasının önüne geçilerek, örgütün etkin bir üyesi haline getirilebilir. Doğru şekilde planlanmış bir oryantasyon eğitim programı çalışanların güvenlik ve ait olma duygularını geliştirerek çalışanların özgüvenini arttırabilir (Mathis ve Jakson, 1997: 158, Karakaya, 2014: 4). Ayrıca çalışanların kurumdaki başarıları ve devamlılıkları önemli ölçüde oryantasyon eğitim sürecinin sonucuna bağlıdır (Şimşek ve Öge, 2011, 151-152). 
Oryantasyon eğitimi ile çalışanlara işyerinde ihtiyaç duyacağı bilgiler en doğru şekilde aktarılmaktadır. Şayet oryantasyon eğitimi düzenlenmez ise çalışanlar ihtiyaç duydukları bu bilgileri etrafında bulunan çalışma arkadaşlarından öğrenmektedirler. $\mathrm{Bu}$ da gerekli olan bilgilerin yanlış veya eksik aktarılmasına neden olmaktadır. Bu durumun önüne geçebilmek için yeni işe alınan çalışanlara belirli programlar dahilinde oryantasyon eğitimin verilmesi gerekmektedir (Byars ve Rue, 2000: 205).

Nitekim bu doğrultuda turizm işletmelerinde yapılan bir araştırmada oryantasyon eğitiminin yeni işgörenleri işe ve işletmeye uyumlaştırıcı etkisinden dolayı işgören devir oranını düşürdüğü belirtilmiştir. Aynı çalışmada işe alma sürecinde yaşanan eksikliklerin oryantasyon eğitimiyle giderildiği ifade edilmiştir (Seymen,2002: 25). Organize sanayi bölgelerinde yapılan bir araştırmada ise oryantasyon eğitimi alan çalışanların örgütsel bağlılığının daha yüksek olduğu, örgüte bağlı çalışanların işten ayrılma niyetlerinin düşük olduğu belirtilmiştir (Çakır ve Kacır, 2018, 145). Otel çalışanlarına yönelik bir çalışmada ise oryantasyon eğitiminin çalışanların performansını arttırıcı etki yaptığı sonucuna ulaşılmıştır (Yaylı ve Temiraliyeva, 2006: 96). Bu çalışmaların sonuçları da oryantasyon eğitimin öneminin işletmeler açısından ne derece önemli olduğunu ortaya koymaktadır.

\section{Oryantasyon Eğitiminin Kapsamı ve İçeriği}

Oryantasyon eğitiminin kapsamı işletmenin faaliyette bulunduğu sektörden sektöre farklılık göstermektedir. İşletmenin ölçek büyüklüğü, amaç ve hedefleri, işletmenin üretmiş olduğu ürün ve hizmetler, eğitim süresi gibi faktörler oryantasyon eğitiminin kapsamını belirlemektedir (Ataklı, 1998: 12). Küçük ölçekli işletmelerde işe alımlar az sayıda ve belirsiz dönemlerde olduğundan bu işletmelerde dar kapsamlı programlar, büyük ölçekli işletmelerde alımlar toplu ve belirli dönemlerde olduğundan daha geniş kapsamlı eğitim programları düzenlenmektedir (Karakaş, 2014: 4). Bu süreçte örgütün yapısı ve tarihçesi, işletmenin misyonu ve vizyonu, değerleri vb. bilgilerin çalışanlara verilmesi gerekmektedir (Okakın, 2008; 79).

Oryantasyon eğitim içeriği hazırlanırken, eğitim programlarının eğitime katılanların dinlemesinden öte onların eğitim sürecine aktif olarak katılabilecekleri şekilde tasarlanması gerekmektedir (Noe ve diğ., 2009: 202, Tiyek, 2014: 337). Oryantasyon eğitimini işletme ve çalışan ile ilgili konular olarak iki başlıkta değerlendirebiliriz. İşletmeye ilişkin olarak, işletmenin geçmişi, yapısı, örgütlenmesi, fiziki olanaklar, ürün ve hizmetler, işletme politikaları ve kuralları, disiplin kuralları, iş güvenliği ve sağlığ 1 gibi konular işe alınan çalışanlara ilişkin olarak, ödeme çizelgeleri ve günleri, izinler ve tatiller, dinlenme süreleri, eğitim olanakları, sigorta olanakları, emeklilik programları, görevler ve terfiler, maaşlar, fazla çalışma, tatil ücreti, vardiya farkı, kar payları ve aralıkları vb. özlük konularının eğitim programında bulunması gerekmektedir (Byars ve Rue, 2000: 207). Ayrıca işletmenin oryantasyon eğitimi içerisinde yer alan iş alışkanlıkları, çalışanın performansı, iş ahlakı ve iş etiği vb. özellikler işletme tarafından yeni çalışanın başarısı için gerekli olduğu düşünülmektedir. Bununla bağlamda işletmedeki kariyer olanakları, çalışanlara karşı eşit davranış ve ücret 
artırımı tutarları ve periyotları gibi konular ile ilgili beklentiler de işletme tarafından işe yeni başlayan çalışanlara anlatılmalıdır (Phillips, 1987: 14).

\section{Metedoloji}

\subsection{Araştırmanın Amacı, Kapsamı ve Yöntemi}

Araştırmada işe yeni alınan çalışanlara verilen oryantasyon eğitiminin etkinliğinin araştırılması amaçlanmıştır. Bu doğrultuda çalışanlara eğitim sonunda oryantasyon eğitiminin değerlendirilmesine yönelik işe başladıktan sonra ise oryantasyon eğitiminin iş hayatında uygulanmasına yönelik anket uygulanmıştır. Böylelikle oryantasyon eğitim programının doğru şekilde tasarlanıp tasarlanmadığ çalışanlardan elde edilen veriler ışığında değerlendirilmiştir.

Araştırmanın evreni tarım sektöründe faaliyet gösteren bir bölge birliğine bağlı kooperatif işletmelerinde oryantasyon eğitimine katılmış çalışanlardır. Fakat belirlenen işletmede işe alımlar belirli yıllarda toplu olarak gerçekleştiğinden çalışmamızın doğru sonuçlar vermesi açısından 2019 yılı Kasım ayında toplu olarak işe alınan çalışanlar örneklem olarak seçilmiştir. Bu bağlamda 2019 yılında işe alınan 89 kişiye anket formu düzenlenmiştir.

Araştırma verilerinin toplanmasında anket tekniği kullanılmıştır. Oryantasyon eğitimi değerlendirme anket formu ve oryantasyon eğitimi- çalışma hayatı değerlendirme anket formları literatür taraması sonucu oluşturulmuş olup anket formu uygulama öncesinde geçerlilik ve güvenirlilik konusunda ikisi ilgili kurumda çalışan iki uzman ve ikisi akademisyen olmak üzere dört kişi tarafından değerlendirilerek son halini almıştır. Çalışmada kullanılan ölçeklerin güvenirlik düzeylerinin belirlenmesi için güvenirlik analizi yapılmış ve chronbach alfa katsayıları elde edilmiştir. Oryantasyon eğitimi değerlendirme ölçeği ve oryantasyon eğitimi -çalışma hayatı değerlendirme ölçekleri için chronbach alfa katsayıları sırasıyla 0,702 ve 0,815 olarak elde edilmiştir. Sonrasında örneklem içerisinde yer alan on çalışana pilot uygulama yapılarak, soruların anlaşılırlığı ve anket tamamlama süresine ilişkin bilgiler elde edilmiştir.

Anket formu üç bölümden oluşmaktadır. İlk bölüm demografik soruları içermekte olup 3 sorudan oluşmaktadır. İkinci bölümde oryantasyon eğitimine katılan çalışanlara eğitim sonrası yapılan değerlendirme sorularından üçüncü bölüm ise oryantasyon eğitimi- çalışma hayatı değerlendirme sorularından oluşmaktadır. Oryantasyon eğitim değerlendirme kısmında eğitim programı, eğiticiler, eğitim ortamı vb. konularının değerlendirildiği 16 sorudan, oryantasyon eğitimi- çalışma hayatı değerlendirme sonuçları ise 11 sorudan oluşmaktadır. Anket formlarında 5'li likert ölçeği kullanılmış olup ölçekte bulunan ifadeler (1) Hiç Katılmıyorum, (2) Katılmiyorum, (3) Kararsızım, (4) Katılıyorum, (5) Kesinlikle Katılıyorum değerlerinden oluşmaktadır. Ayrıca literatür taraması sonucu eğitim içeriğinde olması 
gereken konu başlıkları belirlenerek çalışanlara bu konular hakkında bilgilendirmenin yeterli olup olmadığı sorulmuştur.

Çalışanlara oryantasyon eğitiminin sonunda eğitim değerlendirme anketi uygulanmıştır. Sonrasında ise oryantasyon eğitimine katılanların aldıkları eğitim ile çalışma hayatında bu eğitimde öğrendiklerini karşılaştırabilmeleri için verileri toplamada kullanılan anket çalışanlara çalışmaya başladıktan 9 ay sonra (Temmuz 2020) tarihinde uygulanmıştır. 9 aylık bu süre eğitim programı yöneticileri ve araştırmacı tarafından çalışanların kurumu tanımaları ve işi öğrenmeleri için yeterli bir süre olarak değerlendirilmektedir. Kurumda personel alımları toplu olarak yapıldığından araştırmaya katılan bütün çalışanlar kurumda 9 aydır çalışmaktadır.

\subsection{Araştırmanın Bulguları}

\subsubsection{Demografik Özelliklere İlişkin Bulgular}

Araştırmaya katılan çalışanların demografik özelliklerine ilişkin bulgular Tablo'1 de sunulmuştur. Tablo incelendiğinde ankete katılan çalışanların \%25,8'i kadın, \%74,2'sinin ise erkek olduğu belirtilmiştir. Ankete katılan çalışanların eğitim durumu incelendiğinde \%11,2 'sinin önlisans, \%79,9'unun lisans ve \%8,9'unun ise yüksek lisans mezunu olduğu mezun oldukları okullar açısından incelendiğinde \%57,3'ünün İ̈BF mezunu, \%42,7'sinin ise Ziraat Fakültesi mezunu olduğu görülmektedir.

Tablo 1: Çalışanlara Ait Demografik Özellikler

\begin{tabular}{|l|l|c|c|}
\hline \multicolumn{2}{|l|}{ Değișkenler } & Frekans & \% \\
\hline \multirow{3}{*}{ Cinsiyet } & Kadın & 23 & 25,8 \\
\cline { 2 - 4 } & Erkek & 66 & 74,2 \\
\hline \multirow{3}{*}{$\begin{array}{l}\text { Ĕgitim } \\
\text { Durumu }\end{array}$} & Önlisans & 10 & 11,2 \\
\cline { 2 - 4 } & Lisans & 71 & 79,9 \\
\cline { 2 - 4 } $\begin{array}{l}\text { Mezun Olduğu } \\
\text { Okul }\end{array}$ & Yüksek Lisans & 8 & 8,9 \\
\cline { 2 - 4 } & İ̈BF & 51 & 57,3 \\
\cline { 2 - 4 } & Ziraat Fak. & 38 & 42,7 \\
\hline
\end{tabular}

\subsubsection{Oryantasyon Eğitiminin Değerlendirilmesine İlişkin Bulgular}

Ankete katılan çalışanların oryantasyon eğitimine ilişkin değerlendirmeleri Tablo 2'de sunulmuştur. Bu doğrultuda oryantasyon eğitim değerlendirmesinde dikkat çekici hususlardan “ Almış olduğum eğitim beklentilerimi karşıladı.” ifadesine katılımcıların \%66,29'u kesinlikle katılıyorum \%28,09'u katılıyorum cevabı vermiş olup bu ifadenin ortalaması da 4.61 gibi yüksek bir değer çıkmıştır. Ayrıca "Eğitimi amacına uygun buldum." ifadesine katılımcıların vermiş oldukları cevapların ortalaması 4,64 gibi bir değeri göstermektedir. Bu durumda eğitimin amacına ulaştığını ve çalışanların beklentilerini karşıladığı göstermektedir. Diğer önemli bir husus 
katılımcıların" Eğitimin süresinin belirtilen hedeflere ulaşmada yeterliydi." ifadesine \%28'9 hiç katılmıyorum, \%30,34'ü katılmıyorum görüşünü dile getirmiş olup bu değerlerin ortalaması 2,62 gibi düşük bir değeri göstermektedir. Bu sonuçlarda oryantasyon eğitim süresinin çalışanlar tarafından yetersiz görüldüğü belirtmektedir. Değerlendirme formunda katılımcıların vermiş olduğu cevaplarda dikkat çeken hususlardan biride eğitimcilerin değerlendirilmesinde katılımcıların vermiş olduğu cevaplardır. Katılımcılar "Eğitimci katılımcıların fikir ve paylaşımlarını önemsedi." ifadesine \%66,29'u kesinlikle katılıyorum, \%31,46's1 katılıyorum, "Eğitimci uygun iletişim ortamı sağladı." ifadesine \%64,04 kesinlikle katılıyorum, \%29,21 katılıyorum şeklinde görüş bildirmişler. Bu ifadelerin ortalama değerleri sırasıyla 4,65 ve 4,60 olduğu görülmektedir. $\mathrm{Bu}$ bulgular eğitimcinin eğitime katılan çalışanlar ile iyi bir iletişim kurduğunu onların görüş ve önerilerini dikkate alarak katılımcı bir eğitim yaklaşımını benimsediğini göstermektedir. Oryantasyon eğitim değerlendirme anketinde diğer bir önemli husus katılımcıların "Mümkün olursa aynı eğitimi tekrar almak isterim." ifadesine vermiş oldukları cevaplardır. Bu ifadeye katılımcıların \%74,16'sı kesinlikle katılıyorum, \%20,22'si katılıyorum şeklinde cevap vermiştir. Bu ifadelerin ortalaması ise 4,69 olup oldukça yüksek bir değeri göstermektedir. Bu bulgularda katılımcıların oryantasyon eğitiminin yararlı ve verimli geçtiğini, çalışanların oryantasyon eğitiminden memnun olduğunu göstermektedir.

Tablo 2: Çalışanların Oryantasyon Eğitimine İlişkin Değerlendirmeleri

\begin{tabular}{|c|c|c|c|c|c|c|c|c|c|c|c|}
\hline Anket Soruları & 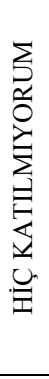 & 8 & 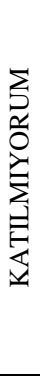 & $8^{\circ}$ & 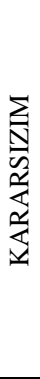 & $a^{2}$ & 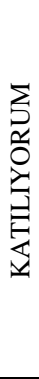 & $b^{0}$ & 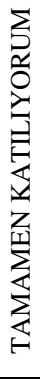 & $b^{0}$ & Ort. \\
\hline $\begin{array}{l}\text { Almış olduğum eğitim } \\
\text { beklentilerimi karşıladı. }\end{array}$ & 0 & 0,00 & 0 & 0,00 & 5 & 5,62 & 25 & 28,09 & 59 & 66,29 & 4,61 \\
\hline $\begin{array}{l}\text { Eğitimi amaca uygun } \\
\text { buldum. }\end{array}$ & 0 & 0,00 & 0 & 0,00 & 3 & 3,37 & 26 & 29,21 & 60 & 67,42 & 4,64 \\
\hline Eğitimi güncel buldum. & 0 & 0,00 & 2 & 2,25 & 9 & 10,11 & 28 & 31,46 & 50 & 56,18 & 4,42 \\
\hline $\begin{array}{l}\text { Eğitimin içeriği ilgi } \\
\text { çekiciydi. }\end{array}$ & 0 & 0,00 & 3 & 3,37 & 9 & 10,11 & 29 & 32,58 & 48 & 53,93 & 4,38 \\
\hline $\begin{array}{l}\text { Eğitim beni çalışma } \\
\text { koşullarına etkin olarak } \\
\text { hazırladı. }\end{array}$ & 2 & 2,25 & 5 & 5,62 & 13 & 14,61 & 30 & 33,71 & 39 & 43,82 & 4,11 \\
\hline $\begin{array}{l}\text { Eğitimin süresi belirlenen } \\
\text { hedeflere ulaşmada } \\
\text { yeterliydi. }\end{array}$ & 2 & 2,25 & 5 & 5,62 & 18 & 20,22 & 38 & 42,70 & 26 & 29,21 & 2,62 \\
\hline
\end{tabular}




\begin{tabular}{|c|c|c|c|c|c|c|c|c|c|c|c|}
\hline $\begin{array}{l}\text { Eğitimde öğrendiklerim } \\
\text { günlük iş yaşamıyla } \\
\text { ilgiliydi. }\end{array}$ & 1 & 1,12 & 0 & 0,00 & 10 & 11,24 & 33 & 37,08 & 45 & 50,56 & 4,36 \\
\hline $\begin{array}{l}\text { Eğitimcinin sunumu açık } \\
\text { ve anlaşılırdı. }\end{array}$ & 0 & 0,00 & 1 & 1,12 & 9 & 10,11 & 34 & 38,20 & 45 & 50,56 & 4,38 \\
\hline $\begin{array}{l}\text { Eğitimci uygun yöntem ve } \\
\text { teknikleri kulland. }\end{array}$ & 0 & 0,00 & 1 & 1,12 & 5 & 5,62 & 31 & 34,83 & 52 & 58,43 & 4,52 \\
\hline $\begin{array}{l}\text { Eğitimci açık anlaşılır bir } \\
\text { dil kullandı. }\end{array}$ & 0 & 0,00 & 0 & 0,00 & 5 & 5,62 & 37 & 41,57 & 47 & 52,81 & 4,47 \\
\hline $\begin{array}{l}\text { Eğitimci süreyi verimli } \\
\text { kullandı. }\end{array}$ & 0 & 0,00 & 3 & 3,37 & 10 & 11,24 & 28 & 31,46 & 48 & 53,93 & 4,36 \\
\hline $\begin{array}{l}\text { Eğitimci katılımcıların fikir } \\
\text { ve paylaşımlarını } \\
\text { önemsedi. }\end{array}$ & 0 & 0,00 & 0 & 0,00 & 2 & 2,25 & 28 & 31,46 & 59 & 66,29 & 4,65 \\
\hline $\begin{array}{l}\text { Eğitimci uygun bir iletişim } \\
\text { ortamı sağladı. }\end{array}$ & 0 & 0,00 & 0 & 0,00 & 6 & 6,74 & 26 & 29,21 & 57 & 64,04 & 4,60 \\
\hline $\begin{array}{l}\text { Bu eğitimi kurumun tüm } \\
\text { personelinin alması faydalı } \\
\text { olacaktır. }\end{array}$ & 3 & 3,37 & 4 & 4,49 & 5 & 5,62 & 22 & 24,72 & 55 & 61,80 & 4,34 \\
\hline $\begin{array}{l}\text { Mümkün olursa aynı } \\
\text { eğitimi tekrar almak } \\
\text { isterim. }\end{array}$ & 0 & 0,00 & 3 & 3,37 & 2 & 2,25 & 18 & 20,22 & 66 & 74,16 & 4,69 \\
\hline
\end{tabular}

\subsubsection{Oryantasyon Eğitim İçeriğinin Değerlendirilmesi}

Oryantasyon eğitiminde yer alması gereken konulara ilişkin olarak çalışanların görüşlerine Tablo 3'de yer verilmiştir. Bu doğrultu da eğitim programında olması gereken konulara ilişkin olarak literatür taraması sonucu oluşturulan başlıklar çalışanlar tarafindan değerlendirilmiştir.

Eğitime katılanların \%70,79'u eğitim programında yer alan ”Kooperatif Çalışma Sistemleri” konusunda verilen bilgilerin yeterli olduğunu belirtmişlerdir. Bu durum özellikle kooperatif işletmelerini bilmeyen çalışanların kooperatiflerin çalışma şeklini anlamaları açısından olumlu bir durum olarak görülmektedir. Bununla birlikte çalışanların özlük ve sosyal haklarına ilişkin olarak katılımcıların \%71,91'i özlük ve sosyal hakları konusunda verilen eğitim içeriğinin yeterli olduğunu belirtmektedir. İşyeri çalışanları toplu sözleşmeye bağlı olarak çalıştıklarından özlük ve sosyal hakları bu sözleşme hükümlerine göre düzenlenmektedir. Bundan dolayı çalışanlar özlük ve sosyal haklarını daha kolay şekilde öğrenebilmektedir.

Katılımcıların \%61,62'si "Yönetici ve çalışma arkadaşlarıyla tanıştırılma" hususunun yetersiz olduğunu dile getirmişlerdir. Oryantasyon eğitiminin amaçlarından olan personelin işe uyumunun sağlanması için çalışanların birlikte çalışacakları yönetici ve arkadaşlarıyla tanıştırılması uyum süresinin daha kısa sürmesi açısından önemlidir. Bununla birlikte "kariyer imkânlarının anlatılması" kriterini katılımcıların \%66,29'u yetersiz olarak belirtmişlerdir. İşe yeni başlayan her personelin işe başlangıçta kariyer planlamasını yapması çalışanın işe ve örgüte olan bağlılığı artıracaktır. Bundan dolayı 
oryantasyon eğitimlerinde işyerindeki kariyer imkanlarının çalışanlara aktarılması önem arz etmektedir.

Tablo 3: Oryantasyon Eğitim İçeriği Değerlendirme

\begin{tabular}{|l|c|c|c|c|}
\hline \multirow{2}{*}{\multicolumn{1}{c|}{ Değerlendirme Kriterleri }} & \multicolumn{2}{c|}{ Yetersiz } & \multicolumn{2}{c|}{ Yeterli } \\
\cline { 2 - 5 } & $\begin{array}{c}\text { Kişi } \\
\text { Sayısı }\end{array}$ & \% & $\begin{array}{c}\text { Kişi } \\
\text { Sayısı }\end{array}$ & \% \\
\hline Kurumun Yapısı ve Kültürü & 38 & 42,70 & 51 & 57,30 \\
\hline Kooperatif Çalışma Sistemleri & 26 & 29,21 & 63 & 70,79 \\
\hline Özlük ve Sosyal Hakları & 25 & 28,09 & 64 & 71,91 \\
\hline Yönetici ve Çalışma Arkadaşlarıyla Tanıştırılma & 61 & 61,62 & 38 & 38,38 \\
\hline Kariyer İmkânlarının Anlatılması & 59 & 66,29 & 30 & 33,71 \\
\hline Yapılacak İşin Tanıtımı & 40 & 44,94 & 49 & 55,06 \\
\hline
\end{tabular}

\subsubsection{Oryantasyon Eğitimi- Çalışma Hayatının Değerlendirilmesi İle İlgili Araştırma Bulguları}

$\mathrm{Bu}$ bölümde oryantasyon eğitimine katılan çalışanların çalışmaya başladıktan sonra oryantasyon eğitiminde elde ettikleri kazanımların çalışma hayatı ile karşılaştırılmasının çalışanlar tarafından değerlendirilmesi ele alınmaktadır. Bu doğrultuda çalışanların görüşleri Tablo 4'de sunulmuştur. "Oryantasyon eğitiminde verilen bilgiler sayesinde işe uyum sağlamam daha kolay oldu." ifadesine çalışanların \% 62, 92'si kesinlikle katılıyorum \% 28, 09'u katılıyorum, “Oryantasyon eğitimi alamadan işe adapte olmak daha kolaydır" ifadesine ise katılımcıların \%62,92'si hiç katılmıyorum \% $16,85^{\prime} \mathrm{i}$ ise katılmıyorum cevabı vermiştir. Bu ifadelerin ortalama değerleri sırasıyla 4,52 ve 1,70 olduğu görülmektedir. Bu durum oryantasyon eğitiminin çalışanın işe uyum sağlamasını kolaylaştırmak, daha kısa sürede adapte olmasını sağlamak amacını yerine getirdiğini göstermektedir. Çalışanların veriş oldukları cevaplarda öne çıkan bir husus "Almış olduğum oryantasyon eğitimi ile işe ve kuruma karşı motivasyonum arttı." İfadesinin ortalama değeri 4,51 gibi yüksek bir değeri göstermektedir. Bu sonuçlar oryantasyon eğitiminin işe bağlılı̆̆ yerine getirdiğini çalışanların vermiş oldukları cevaplarla göstermektedir. Diğer önemli bir husus katılımcıların "Aldığım oryantasyon eğitiminin çok faydalı olduğunu düşünüyorum” ifadesine çalışanların \% 68,54'ü kesinlikle katılıyorum “ İşe yeni başlayan her çalışan kesinlikle oryantasyon eğitimi almalıdır." ifadesine ise çalışanların \% 65,17'si kesinlikle katılıyorum şeklinde cevap vermişlerdir. Bu ifadelerin ortalaması sırasıyla 4,31 ve 4,60 olduğu görülmektedir. Bu bulgular oryantasyon eğitiminin çalışanların iş hayatını daha da kolaylaştırdığını ve çalışanlara yarar sağladığını göstermektedir. Diğer önemli bir husus "Oryantasyon eğitiminde verilen uygulamaya dönük örneklerin çalışmaya başlayınca ne kadar uygun olduğunu anladım." ifadesine 
çalışanların \%32,59’u kararsızım ve katılmıyorum şeklinde cevap vermişlerdir. Bu durum farklı fakülte mezunlarına aynı eğitimin verilmesinden dolayı özellikle ziraat fakültesi mezunları için uygulamaya yönelik bu örneklerin eğitim içeriğinde tam olarak yer almamasından kaynaklanmaktadır. Bu nedenle oryantasyon eğitim programı düzenlenirken çalışanların eğitim düzeyinin ve mezun oldukları okulların dikkate alınması eğitim programının daha da verimli olmasını sağlayacaktır.

\section{Tablo 4: Oryantasyon Eğitimi- Çalışma Hayatı Değerlendirme Sonuçları}

\begin{tabular}{|c|c|c|c|c|c|c|c|c|c|c|c|}
\hline ANKET SORULARI & 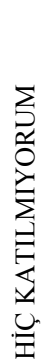 & o & 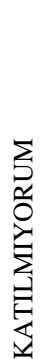 & o & 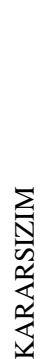 & $0^{\circ}$ & 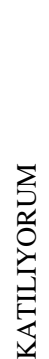 & $0^{\circ}$ & 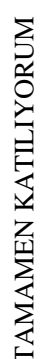 & $\therefore$ & Ort. \\
\hline $\begin{array}{l}\text { Oryantasyon eğitiminde verilen } \\
\text { bilgiler sayesinde işe uyum } \\
\text { sağlamam daha kolay oldu }\end{array}$ & 0 & 0,00 & 0 & 0,00 & 8 & 8,99 & 25 & 28,09 & 56 & 62,92 & 4,52 \\
\hline $\begin{array}{l}\text { Oryantasyon eğitiminde verilen } \\
\text { uygulamaya dönük örneklerin } \\
\text { çalışmaya başlayınca ne kadar } \\
\text { uygun olduğunu anladım }\end{array}$ & 3 & 3,37 & 5 & 5,62 & 21 & 23,60 & 28 & 31,46 & 32 & 35,96 & 3,91 \\
\hline \begin{tabular}{|lrr} 
Oryantasyon & \multicolumn{2}{r|}{ eğitimininin } \\
çalışanların & daha etkin \\
çalışmasını & sağlayacağına \\
inanıyorum & \\
\end{tabular} & 0 & 0,00 & 3 & 3,37 & 10 & 11,24 & 30 & 33,71 & 46 & 51,69 & 4,34 \\
\hline $\begin{array}{l}\text { Oryantasyon eğitimi almadan } \\
\text { da işe adapte olmak kolaydır }\end{array}$ & 56 & 92 & 15 &, 85 & 10 & 24 & 5 & 62 & 3 & 37 & 70 \\
\hline $\begin{array}{l}\text { Oryantasyon eğitimi almamın, } \\
\text { almayan çalışma arkadaşlarıma } \\
\text { göre bana avantaj sağladığın } \\
\text { düşünüyorum }\end{array}$ & 0 & 00 & 2 & 2,25 & 11 & 12,36 & 23 & 25,84 & 53 & 59,55 & 4,43 \\
\hline $\begin{array}{l}\text { Almış olduğum oryantasyon } \\
\text { eğitimi ile işe ve kuruma karşı } \\
\text { motivasyonum arttı }\end{array}$ & 1 & 12 & 3 & 3,37 & 5 & 5,62 & 21 & 23,60 & 59 & 66,29 & 4,51 \\
\hline \begin{tabular}{lr} 
Aldığım & \multicolumn{2}{r}{ oryantasyon } \\
eğitiminin çok faydalı \\
olduğunu düsünüyorum
\end{tabular} & 1 & 1,12 & 3 & 3,37 & 7 & 7,87 & 17 & 19,10 & 61 & 68,54 & 4,31 \\
\hline $\begin{array}{l}\text { Oryantasyon eğitimi ile } \\
\text { edindiğim bilgiler uygulamada } \\
\text { karşılaştığım pek çok sorunu } \\
\text { kolayca çözmemde bana } \\
\text { yardımcı oldu }\end{array}$ & 5 & 5,62 & 10 & 11,24 & 20 & 22,47 & 30 & 33,71 & 24 & 26,97 & 3,67 \\
\hline $\begin{array}{l}\text { İşe yeni başlayan her çalışan } \\
\text { kesinlikle oryantasyon eğitimi } \\
\text { almalıdır }\end{array}$ & 0 & 0,00 & 2 & 2,25 & 4 & 4,49 & 25 & 28,09 & 58 & 65,17 & 4,60 \\
\hline
\end{tabular}




\begin{tabular}{|c|c|c|c|c|c|c|c|c|c|c|c|}
\hline $\begin{array}{l}\text { Oryantasyon eğitimine } \\
\text { katılmasaydım daha düşük } \\
\text { performans gösterebilirdim }\end{array}$ & 4 & 4,49 & 5 & 5,62 & 12 & 13,48 & 30 & 33,71 & 38 & 42,70 & 3,99 \\
\hline $\begin{array}{lr}\text { Oryantasyon } & \text { eğitiminde } \\
\text { anlatılanlar ile } & \text { uygulamada } \\
\text { karşıllaşılanlar } & \text { arasında } \\
\text { farklılıllar } & \text { olduğunu } \\
\text { düşünüyorum } & \end{array}$ & 33 & 37,08 & 28 & 31,46 & 15 & 16,85 & 8 & 8,99 & 5 & 5,62 & 2,11 \\
\hline
\end{tabular}

\section{Sonuç ve Değerlendirme}

Bu çalışmada, çalışanların almış oldukları oryantasyon eğitimini ve bu eğitimin çalışma hayatındaki etkisini değerlendirmesi ve böylelikle oryantasyon programının etkili ve verimli olabilmesi için nelerin önemli olduğu belirlenmeye çalışılmıştır. Bu doğrultuda yeni işe alınan 89 çalışana 3'ü demografik sorulardan ve üç bölümden oluşan toplam 33 sorudan oluşan anket yüzyüze şekilde dağıtılmıştır. Araştırmaya katılanların \%74,2'si erkek, \%79,9'u lisans mezunu, \%57,3'ü İ̈BF mezunu çalışanlardan oluşmaktadır.

Kooperatifler organizasyon yapıları, kültürleri, işleyişleri bakımından diğer işletmelerden farklılıklar göstermektedir. Kooperatifler daha çok taşra teşkilatlanmasına sahip olup az sayıda personel ile çalışmalarına devam etmektedir. Bu bağlamda oryantasyon eğitimi bütün işletmeler için önemli olduğu gibi kooperatif işletmeleri açısından da büyük önem arz etmektedir. Çünkü çalışanlar oryantasyon eğitiminde edinmiş oldukları iş ile ilgili bilgiler ile kooperatiflerde çalışmaya başladıklarında yapılan işleri karşılaştırarak işlerin ne kadar doğru yapıldığını görmektedir.

Oryantasyon eğitiminin çalışma hayatındaki etkinliğinin araştırıldığı çalışma da; katılımcıların büyük çoğunluğu tarafından işe başlayan herkese oryantasyon eğitiminin verilmesi gerektiği dile getirilmiştir. Çalışanlar oryantasyon eğitiminde işletmeyi, çalışma ortamını daha yakından tanıma imkanı bulmakta buda onların işe adaptasyon süreçlerini kısaltmaktadır. Ayrıca oryantasyon eğitiminde verilen bilgilerde çalışanların işe uyumunu kolaylaştırmaktadır.

Oryantasyon eğitiminin içeriğine ilişkin olarak kooperatifçilik sisteminin, yapısının ve kültürünün, kooperatiflerin çalışma sitemlerinin, çalışanların özlük ve sosyal haklarının eğitimde çalışanlara yeterince aktarıldığ 1 katılımcıların ifadelerinden anlaşılmaktadır. Fakat özellikle çalışanların kariyer imkânlarına ilişkin bilgilendirmenin yeterince yapılmadığı, çalışanların yönetici ve çalışma arkadaşlarıyla tanıştırılmasında yetersiz kalındığı çalışanlar tarafından belirtilmiştir. Özellikle çalışanlar tarafindan istenen bireysel kariyer planlamalarını yapabilmeleri için oryantasyon eğitimlerinde çalışanların kariyer imkanlarının anlatılması çalışanların işe ve örgüte bağlılığı açısından daha doğru olacaktır. Bununla birlikte çalışanların iş ortamına daha kısa sürede uyum sağlayabilmesi ve işe başladığında yabancılık çekmemesi için oryantasyon eğiminde yöneticiler ve çalışma arkadaşlarıyla tanıştırılması gerekmektedir. 
Oryantasyon eğitiminin değerlendirilmesinde dikkat çeken önemli bir husus ise eğitim süresinin belirlenen hedeflerin gerçekleşmesinde yeterli olmadığının katılımcıların büyük çoğunluğu tarafından belirtilmiş olmasıdır. Oryantasyon eğitiminin belirlenen amaç ve hedeflere ulaşması için eğitim programının içeriğinin ve süresinin doğru şekilde planlanması gerekmektedir. Aksi taktirde oryantasyon eğitiminin başarıya ulaşması mümkün görünmemektedir.

Araştırma yapılan kooperatif işletmesinde çalışanların işe alımları belirli tarihlerde toplu şekilde yapılmaktadır. Bu alımlarda farklı bölümlerden mezun çalışanlar işe alınmakta olup oryantasyon eğitimleri işe alınan çalışanlara toplu şekilde verilmektedir. $\mathrm{Bu}$ doğrultuda özellikle ziraat mühendisleri yapacakları işlerin farklı olduğunu eğitimin mezun olunan bölümlere göre ayrı olarak verilmesi ve eğitim içeriğinin de buna göre düzenlenmesi gerektiğini belirtmişlerdir. Bu durum özellikle uygulamaya yönelik verilen örneklerin ve işe ilişkin bilgilerin her grubun özelliğine göre düzenlenmesi açısından önemlidir.

Oryantasyon eğitimine ilişkin yapılan çalışmalarda oryantasyon eğitiminin örgütsel bağlılığı arttırdığı dolayısıyla örgütsel sinizmi azalttığı, personel devir oranını düşürdüğü çalışanların motivasyonunu arttırdığı görülmektedir. Bu bağlamda iyi bir şekilde tasarlanmış oryantasyon eğitiminin çalışanların verimliliğini ve işletmeye olan katkısını da arttıracaktır. Bu doğrultuda kooperatiflerde oryantasyon eğitimine yönelik olarak yapılan bu çalışma literatürde daha önce yapılan çalışmaları desteklemektedir. Kooperatif işletmelerinde oryantasyon eğitimine ilişkin bir çalışma yapılmamıştır. Bu bağlamda yapılan çalışmanın kooperatiflerde yeni alınacak personele uygulanacak oryantasyon eğitimlerinde hangi hususlara dikkat edilmesi gerektiği konusunda fikir vereceği düşünülmektedir. Bu çalışmanın kısıtları arasında çalışmanın 89 kişilik bir örneklem grubu ile yapılması bundan dolayı sonuçlara ilişkin bir genelleme yapılamaması sayılabilir. Gelecekte yapılacak araştırmalar daha büyük bir örneklem grubu ile farklı sektörlerde gerçekleştirilerek sektörler veya işletmeler arasındaki oryantasyon eğitimine yönelik farklılıklar belirlenebilir. 


\section{Kaynakça}

Byars, L. ve Rue, L. (2006). Human Resource Management, Boston, McGraw-Hill: Irwin,

Çakır, E. ve Kacır, Ü.(2018). İşletmelerde Oryantasyon Eğitiminin Örgütsel Sinizme ve Örgütsel Bağlılığa Etkisi: Aydın Organize Sanayi Bölgesinde Bir Uygulama. Adnan Menderes Üniversitesi Sosyal Bilimler Enstitüsü Dergisi. 5(1), 124-149.

Cascio, W. F.(1992). Managing Human Resources, 3. Baskı, Newyork: Mc-Graw-Hill

Çetin,C. Elmalı, E. ve Arslan M.L. (2018). İnsan Kaynakları Yönetimi, İstanbul: Beta Yayınevi

De Cenzo, D. A. ve Robbins S.P. (1996). Human Resource Management. 5. Bask1, New York: John Wileyand Sons

Dessler, G. (1994). Human Resource Management, 6. Bask1, New Jersey: Prentice Hall.

Harvey, D. ve Robert B.B. (1996). Human Resource Management. New Jersey: Prentice Hall.

Karakaş, A. (2014). İnsan Kaynakları Yönetiminde İşe Alıştırma Eğitimi Programlarının Önemi, Dicle Üniversitesi İktisadi ve İdari Bilimler Fakültesi Dergisi. 4(8), 1-14.

Kocabacak, A. (2010). Yeni Çalışanları İşletmede Tutmanın Yolu: Çalışan Oryantasyonu, Perakendecilik Sektöründe Çalışan Oryantasyonu Ve Örgütsel Bağlılık İlişkisi Üzerine Bir Çalışma. SÜ İIBF Sosyal Ekonomik Araştırmalar Dergisi. Cilt 10. S.20, 17-34.

Latif, H. ve Uçkun, G. (2002). Oryantasyon Eğitiminin İçeriği Binek Otomotiv Sektörü. Ístanbul Üniversitesi Işsletme İktisadi Enstitüsü Yönetim Dergisi 13(41), 37-46.

Mathis, R.L. ve Jackson, J.H. (1991). Personnel/Human Resource Management, St Paul:West Publishing.

Mathis, R. ve Jackson, J.H. (1997). Human Resource Management. St Paul: West Publishing Company.

Mestre, M. Stainer, A. ve Stainer, L. (1997). Employee Orientation - The Japanese Approach. Employee Relations, 19(5), 443-456. 
Mirze, S. Kadri. (2010). İşletme, İstanbul: Literatür Yayıncılık

Noe,R.A. Hollenbeck J. R. Gerhart B. ve Wright P. W. (2009). Fundamentals of Human Resource Management, 3. Bask1, New York: Mc Graw-Hill

Phillips, Jack J. (1987). Recruiting, Training and Retraining, New Employees", San Francisco: Jossoy-Bass Inc.

Okakın, N. (2008). Çalışma Hayatında İnsan Kaynakları Yönetimi, İstanbul :Beta Basım Yayın

Seymen, O. (2008). Turizm İşletmelerine Oryantasyon Eğitiminin İnsan Kaynaklan Yönetimi Açısından Önemi ve Buna Yönelik Program Modelinin Oluşturulması. Anatolia: Turizm Araştırmaları Dergisi, Cilt: 13, Sayı 1, 15 26.

Şimşek, M.Ş ve Öge, H.S. (2011). Insan Kaynakları Yönetimi, Konya: Eğitim Yayınevi

Tiyek, R. (2014). Oryantasyon Eğitim Programının Etkinliğinin Değerlendirilmesi: Bir Araştırma. Çankırı Karatekin Üniversitesi Sosyal Bilimler Enstitüsü Dergisi, 5(1), 333-353.

Ünsar, S. (2003). İnsan Kaynakları Yönetiminde Oryantasyon Eğitimi. MESS Mercek Dergisi, 8(28).

Yaylı, A. ve Temiraliyeva K.(2006). Otel İşletmelerinde İşe Alıştırma Eğitiminin İşgören Performansına Etkisi Üzerine Kazakistan'da Bir Uygulama. Ticaret ve Turizm Eğitim Fakültesi Dergisi, Sayı.1, 96-120. 